\title{
Business Process Evaluation and Case Study for Sequential Application of BPM
}

\author{
Young-Woong Song ${ }^{1}$, Hyung-Chul $\mathrm{Lim}^{2}$, and Yoon-Ki Choi ${ }^{3}$ \\ Received March 9, 2012 / Revised April 4, 2012 / Accepted May 7, 2012
}

\begin{abstract}
Adoption and practical application of BPM yet remains at a theoretic and methodological level for many industrial sectors. As for construction industry, adapting BPM into enterprise resource across all business processes could cause problems due to rapid change in corporate operation systems. Furthermore, it is unable to predict potential risks of business process while BPM are being applied. Therefore, applying BPM model to core strategy and individual task seems more effective than applying BPM model to the entire enterprise resource planning. In this paper, we define BPM and suggest a BPM model by analyzing each business unit in order to evaluate each business unit which is included in the business process architecture based on quantitative standards. This paper also presents a sequential application plan for business process model. Finally, a case study is demonstrated for the application of BPM system, focusing on cost management business, which turned out to be a top priority in the aspect of efficiency and ease based on priority analysis.
\end{abstract}

Keywords: BPM(Business Process Management), Cost Management, IT(Information Technology), PI(Process Innovation), Construction Company

\section{INTRODUCTION}

In order to enhance the value of intangible assets of construction firms, it is necessary to establish process management and control system for core business. Furthermore, continuous improvement of business process by eliminating unnecessary elements and using information system supporting BPM(Business Process Management) is required. To achieve these goals, the system, should be differentiated from the existing business process and be interlinked with other management systems. Monitoring the business process over the whole value chain and continuously improving and optimizing the system, the characteristic of BPM should be maintained to be flexible enough to adapt to changes in the construction market environment with agility.

However, the adoption and practical application of BPM remains at the level of theory and methodology for many industrial sectors. Particularly for the construction industry, it still remains in the phase of theoretical approach and is considered for adoption only in a small number of companies. It is difficult for construction firms to adopt a BPM model in full swing because there is no systematic induction of the system established, such as interface between company strategies, BPM diagnosis system and process improvement system.
Since the adoption of BPM model in Korean construction industry is still in its initial stage, the adoption of BPM for enterprise business of construction companies at corporate level means revamping the business structure and entire related systems in the company. Bearing in mind the underlying risks that are likely to arise by adopting BPM at corporate level, it is desirable to introduce BPM step by step, firstly at core business focusing on key strategy. After rectifying any drawbacks found from the feed-back, it could be applicable for all other sectors of business.

This paper suggests a sequential application plan by quantitative criteria of each unit task which is included in business process architecture. Therefore, this paper proposes a BPM model, an algorithm, and a BPM system, focusing on cost management business, which turned out to be a top priority in the aspects of efficiency and ease, based on priority analysis for adoption of BPM model step by step.

\section{BUSINESS PROCESS EVALUATION FOR BPM}

\section{A. Study on BPM adoption}

In 2002, discussion on interest in BPM started by Smith, H. and Fingar, P in their book, 'BPM: The Third

\footnotetext{
${ }^{1}$ MEST-NRF Research Professor, Ph.D., Research Institute of Frontier Technology, Soong sil University, songhero@ ssu.ac.kr

${ }^{2}$ Associate Professor, Ph.D., Dept of Architectural Engineering, Chang won University, hclim@changwon.ac.kr

${ }^{3}$ Associate Professor, Ph.D., Dept of Architectural Engineering, Soong sil University, ykchoi@ ssu.ac.kr(*Corresponding Author)
} 
Wave', with its focus on business process management in fixing separation problems between business and IT(Information Technology). Later, the background of the appearance of BPM, in technological aspect, could be traced in the advanced stage of Workflow and EA(Enterprise Architecture), and finally BPM system advanced to an independent research field.

Elzinga(1995) claimed that BPM is a systematic and analytic approach method to manage business process in a more flexible manner. Smith. H(2003) suggested a scenario adopting BPM, focusing on coordination of applications and Verner(2004) proposed benefits of BPM in terms of general cost saving, time saving, wage saving and process monitoring. Yet, there are few case studies on BPM adoption in the construction industry, as only a small number of construction firms are in the stage of consideration for adoption. However, further study related to BPM system in construction firms is desperately needed since there are not much research done in the field of BPM adoption, its adopting method and system supporting its adoption.

Smith, H(2002) defined BPM, the third wave, as a well-organized and designed activity, managing and improving business processes that raise productivity. As mentioned above, definition of BPM in advanced research is as follows:

TABLE I

DEFINITION OF BPM

\begin{tabular}{c|l}
\hline Author & \multicolumn{1}{|c}{ Definition of BPM } \\
\hline $\begin{array}{c}\text { Smith, H } \\
\text { (2002) }\end{array}$ & $\begin{array}{l}\text { A managing methodology supporting business procedure b } \\
\text { designing, managing and improving the system of busines } \\
\text { organization to raise business productivity, or its softwar } \\
\text { system }\end{array}$ \\
\hline
\end{tabular}

The established definition of BPM presents the concept of enhanced effects such as visibility of business processes and business monitoring.

However, difficulty in enterprise resource planning and feedback followed by corporate core strategy, lack of sequential application plan and sustainable management plan through BPM were pointed as its problem.

\section{B. Current Status of Business Process Management (BPM) in Construction Industry}

Various process management models have been applied adapting to the changing demands and business environment. Under the rapidly changing circumstances, existing process management models need to be advanced and reflect new environment, emerging needs for business process management and particular demands from IT. Along with the advancement, construction companies need to adopt BPM for the following reasons.

TABLE II

RISE OF BPM MODEL FOR PROCESS MANAGEMENT

\begin{tabular}{c|c}
\hline Category & \multicolumn{1}{c}{ Description } \\
\hline $\begin{array}{c}\text { Changing } \\
\text { business } \\
\text { environment } \\
\text { in } \\
\text { construction }\end{array}$ & $\begin{array}{c}\text { Evolution of process management model (diagnosis, } \\
\text { design, system configuration, process implementation, } \\
\text { process monitoring, continued improvement) }\end{array}$ \\
\hline
\end{tabular}

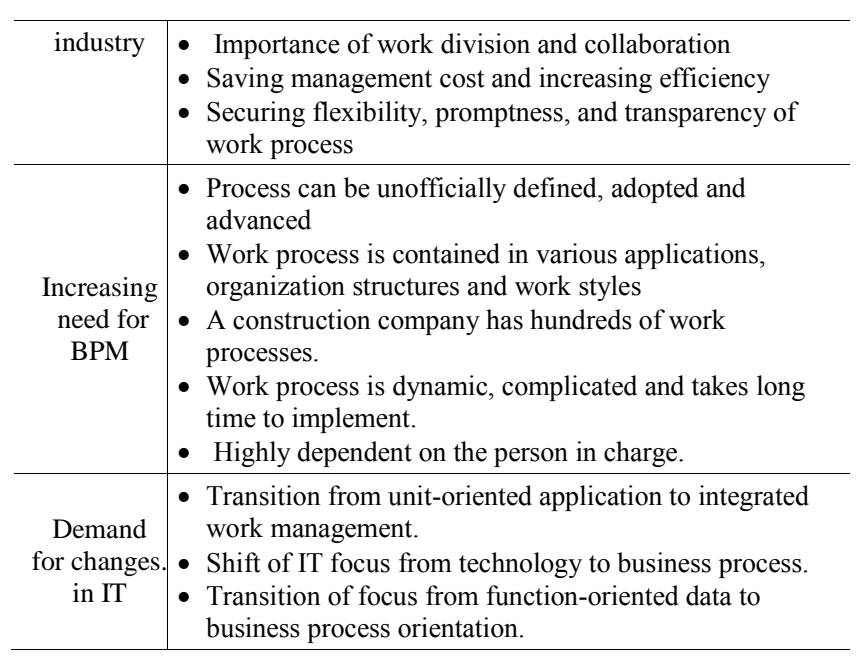

The literature review and expert opinions revealed that the implementation of process management in construction companies is fragmented and limited in scope compared to other industries. Therefore, the outcome is temporary, and the effort to perpetuate the improvement of process management and to link with the information system is insufficient. Table 3 identifies problematic issues and opportunities for improvement.

TABLE III

PROBLEMATIC ISSUES AND OPPORTUNITIES FOR IMPROVEMENT

\begin{tabular}{|c|c|c|c|c|}
\hline Source & \multicolumn{2}{|c|}{ Problem Analysis } & \multicolumn{2}{|c|}{ Suggested Improvement } \\
\hline \multirow{3}{*}{$\begin{array}{c}\text { HANDY } \\
\text { SOFT } \\
(2006)\end{array}$} & \multirow{3}{*}{\multicolumn{2}{|c|}{$\begin{array}{l}\text {-loss of information } \\
\text {-discrepancy of } \\
\text { information between } \\
\text { system } \\
\text {-increased work load } \\
\text { and complexity } \\
\text {-bottlenecks } \\
\text {-demand to expedite } \\
\text { work processes } \\
\text {-paperless company } \\
\text {-need to increase } \\
\text { productivity } \\
\text {-demand for efficient } \\
\text { collaboration and } \\
\text { communication } \\
\text {-demand for easy } \\
\text { change of process } \\
\text {-delayed response to } \\
\text { exceptions }\end{array}$}} & Execution & $\begin{array}{l}\text {-strengthens } \\
\text { execution of } \\
\text { process, balanced } \\
\text { with organization } \\
\text { and IT }\end{array}$ \\
\hline & & & $\begin{array}{l}\text { Perform- } \\
\text { ance } \\
\text { Evaluatio } \\
\mathrm{n}\end{array}$ & $\begin{array}{l}\text {-accurate, real- } \\
\text { time process } \\
\text { evaluation } \\
\text { for progress and } \\
\text { outcomes }\end{array}$ \\
\hline & & & $\begin{array}{l}\text { Response } \\
\text { to } \\
\text { Changes }\end{array}$ & $\begin{array}{l}\text {-secures prompt } \\
\text { process response } \\
\text { to internal and } \\
\text { external changes } \\
\text { of management } \\
\text { environment }\end{array}$ \\
\hline $\begin{array}{c}\text { Report on } \\
\text { BPM } \\
\text { Implement } \\
\text { tion, } \\
\text { Daelim } \\
\text { Industry } \\
(2004)\end{array}$ & \multicolumn{2}{|c|}{$\begin{array}{l}\text {-difficult to identify } \\
\text { work responsibility } \\
\text { and details } \\
\text {-individual decision } \\
\text { and opinions tend to } \\
\text { interfere with } \\
\text { organizational rules } \\
\text { and systems } \\
\text {-lack of flexibility to } \\
\text { cope with changing } \\
\text { market condition }\end{array}$} & \multicolumn{2}{|c|}{$\begin{array}{l}\text {-more applications can be } \\
\text { operated without increasing } \\
\text { number of personnel } \\
\text {-administrators can easily } \\
\text { identify who is responsible for } \\
\text { which process, and progress } \\
\text { status } \\
\text {-improves customer } \\
\text { satisfaction with higher service } \\
\text { effectiveness }\end{array}$} \\
\hline $\begin{array}{c}\text { Bearing } \\
\text { Point } \\
\text { BPM } \\
\text { Implement } \\
\text { tion } \\
\text { Strategy } \\
\text { Report } \\
\text { (2004) }\end{array}$ & $\begin{array}{l}\mathrm{CE} \\
\mathrm{O}\end{array}$ & $\begin{array}{l}\text {-How can we } \\
\text { survive with } \\
\text { competitive } \\
\text { advantage even } \\
\text { in a drastically } \\
\text { changing } \\
\text { business } \\
\text { environment? }\end{array}$ & $\begin{array}{l}\text {-BPM en } \\
\text { easily ide } \\
\text { problems } \\
\text { mechanis } \\
\text { managem } \\
\text { realizes a } \\
\text { that activ } \\
\text { circumsta }\end{array}$ & $\begin{array}{l}\text { es company to } \\
\text { fy internal } \\
\text { stablishes a } \\
\text { for continued } \\
\text { t innovation, and } \\
\text { arning organization } \\
\text { responds to the } \\
\text { e. }\end{array}$ \\
\hline
\end{tabular}




\begin{tabular}{|c|c|c|}
\hline $\begin{array}{l}\mathrm{CF} \\
\mathrm{O} \\
/ \mathrm{C} \\
\mathrm{PO}\end{array}$ & $\begin{array}{l}\text {-What are the } \\
\text { subjects of } \\
\text { innovation to } \\
\text { improve } \\
\text { enterprise-wide } \\
\text { KPIs (stock } \\
\text { price, increased } \\
\text { market share, } \\
\text { cost } \\
\text { competitiveness, } \\
\text { etc.) } \\
\text { performance? }\end{array}$ & $\begin{array}{l}\text {-BPM identifies limitation of } \\
\text { process in achieving KPIs } \\
\text { goals, and turns them into } \\
\text { potential innovation items. }\end{array}$ \\
\hline $\begin{array}{l}\text { CI } \\
\mathrm{O}\end{array}$ & $\begin{array}{l}\text {-Which IT } \\
\text { initiatives are } \\
\text { highly } \\
\text { influential in } \\
\text { improving } \\
\text { management } \\
\text { performance? }\end{array}$ & $\begin{array}{l}\text {-By turning BPM into IT task } \\
\text { for business processes with } \\
\text { clear ROI target, IT can } \\
\text { directly contribute to creating } \\
\text { business outcomes. }\end{array}$ \\
\hline
\end{tabular}

\section{How to adopt method of BPM}

The major role of BPM model is to introduce a business process, in relation with company strategy, into the existing management system. It is a system to improve and visualize the external and internal business process, to execute and control the person and system related to the job in compliance with the process. Furthermore, it must continuously exercise improvement through monitoring the business process for construction firms.

These three elements are the main objects to manage at the early stage of BPM adoption in construction firms, each of which have various sub-elements such as organization structure, business strategies, goals, and so on. Considering these elements, the consideration points for adopting BPM in construction companies are as follows:

- Classify core strategy among the other strategies of the company.

- Choose the core business through strategic evaluation based on external and internal characteristic of construction firms, and analyze organization and subject.

- Examine problems of current processes, grasp the cause, and perform process improvement.

- Visualize core business process.

- Based on the direction of improvement, build a business process system focusing on the process with a distributed business supporting system.

- Through monitoring business process, improve the process by continuously eliminating loss, and become agile at adapting to changes in the construction market environment.

Fig.1. is a conceptual diagram of the definitions and points of consideration of BPM model in construction firms.

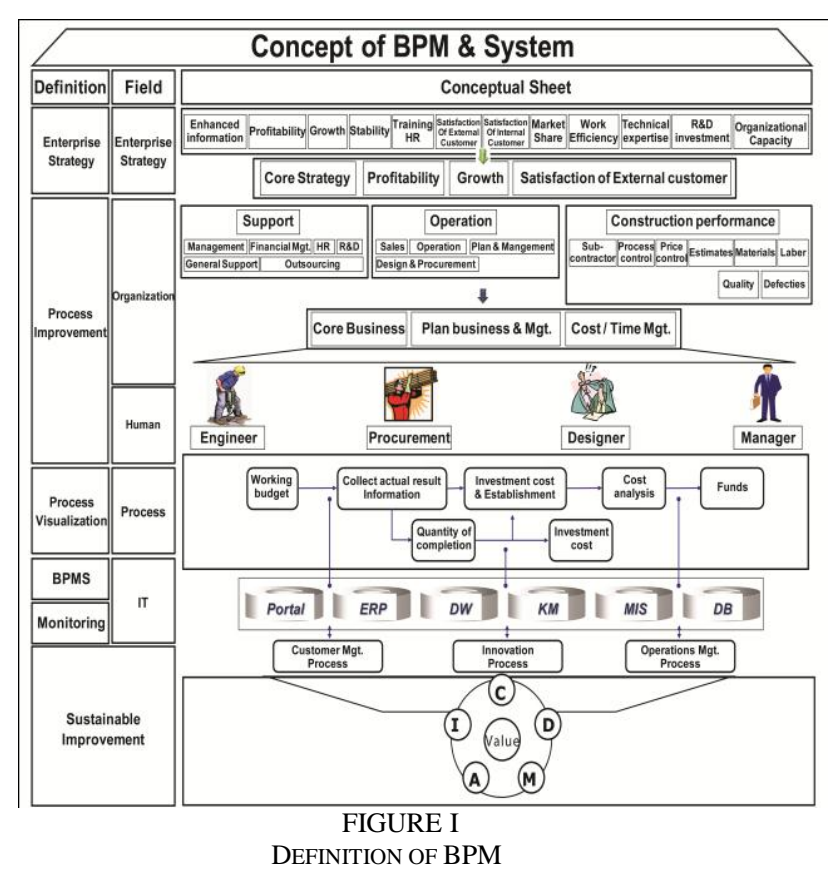

To apply a BPM model, continuous business process improvement by eliminating unnecessary tasks and operation of information system that supports the business process are required. For sequential adoption of the BPM model, key business strategies are needed to be established and priorities for applying BPM to unit tasks in accordance with the key business strategies are needed to be identified. Then, the first-stage goal of improving the business process should be achieved in the order of: 1) work analysis, 2) analysis of relationship between work and application, 3) problem identification and 4) business process improvement. In order to achieve continued improvement of business process with application of BPM model, work implementation, performance management and information management are required. Optimal work structure can be established by continuously extracting wasteful factors in the implementation process and improving them. The BPM model establishes an optimal business process environment by continuously identifying and eliminating valueless tasks in the stages of business process, work implementation, performance management, and information management.

\section{How to evaluate business process}

\section{1) Analyzing business process criteria}

Lee, Byoung-ok (2004) in his research 'the BPM building strategy of manufacturing industry' presents long-term cycle operation and operations involved in many organizations. Choi, Jin-ho (2006) suggested highstrategic priority work and those which need process improvement. The BPM building report of ' $\mathrm{L}$ ' company focused on the importance of business process, operations that involve number of organizations, and operations that need change and automation. The Korea Productivity Center presented work with typical disposal flow, familiar work done by excessive number of people, and work that 
is repeated across departments. Finally, the BPR report of ' $\mathrm{B}$ ' company (1992) focused on dissatisfaction factors and operations that involve more than 30 people in one department. The business criterion for the application of BPM to the existing research is as below. After considering each criterion, two significant findings were found. One is efficiency when business process model adoptions occurred and the other is easiness factor that suggests evaluation standard.

\section{2) How to evaluate sequential BPM application}

Criteria for BPM application consists of Efficiency (EF) and Ease (EA). Efficiency is classified as improvement of corporate value (V), diversity of process (D), and teamwork frequency (T). Ease (EA) consists of IT support (I), frequency of unit task change (C), and sensibility of external change (S).

Conceptual methods of criteria for applying BPM are as in Table 4.

TABLE IV

CONCEPTUAL METHODS OF CRITERIA FOR APPLYING BPM

\begin{tabular}{|c|c|c|}
\hline Criteria & $\begin{array}{c}\text { Evaluation } \\
\text { Point }\end{array}$ & Contents \\
\hline \multirow{3}{*}{ Efficiency } & $\begin{array}{l}\text { Corporate } \\
\text { value } \\
\text { enhancement }\end{array}$ & $\begin{array}{l}\text { The degree of involvement of business } \\
\text { process effects corporate value. In other } \\
\text { words, the importance of the process } \\
\text { enhances corporate value. }\end{array}$ \\
\hline & $\begin{array}{c}\text { Process } \\
\text { complexity }\end{array}$ & $\begin{array}{l}\text { It indicates visualization effect on structural } \\
\text { and non-structural works. Degree of } \\
\text { involvement in the process by related } \\
\text { departments affects complication of the } \\
\text { process } \\
\text { Under the circumstances of a complicated } \\
\text { process and having difficulty to grasp and } \\
\text { monitor progressing status of work, we } \\
\text { could manage operational process by } \\
\text { adopting BPM. In highly operational } \\
\text { process (which is more immanent than } \\
\text { simple-repetitive work) BPM effects are } \\
\text { more significant. }\end{array}$ \\
\hline & $\begin{array}{l}\text { Unit task } \\
\text { teamwork } \\
\text { frequency }\end{array}$ & $\begin{array}{l}\text { A basic majority-led process performed by } \\
\text { variant subjects. When increasing number } \\
\text { of cooperation is involved, the efficiency of } \\
\text { the BPM application increases. }\end{array}$ \\
\hline \multirow{3}{*}{ Easiness } & IT support & $\begin{array}{l}\text { Easiness of BPM application depends on } \\
\text { the level of information system built in the } \\
\text { company }\end{array}$ \\
\hline & $\begin{array}{l}\text { Frequency of } \\
\text { unit task } \\
\text { change }\end{array}$ & $\begin{array}{l}\text { Difficulty and irregularity of managing } \\
\text { process due to frequent change in } \\
\text { organization and management. }\end{array}$ \\
\hline & $\begin{array}{l}\text { Sensibility of } \\
\text { external } \\
\text { change }\end{array}$ & $\begin{array}{l}\text { The environmental effects on business } \\
\text { process resulting in changes of law or } \\
\text { regulation. }\end{array}$ \\
\hline
\end{tabular}

A system of Process criteria is as in Fig.2.

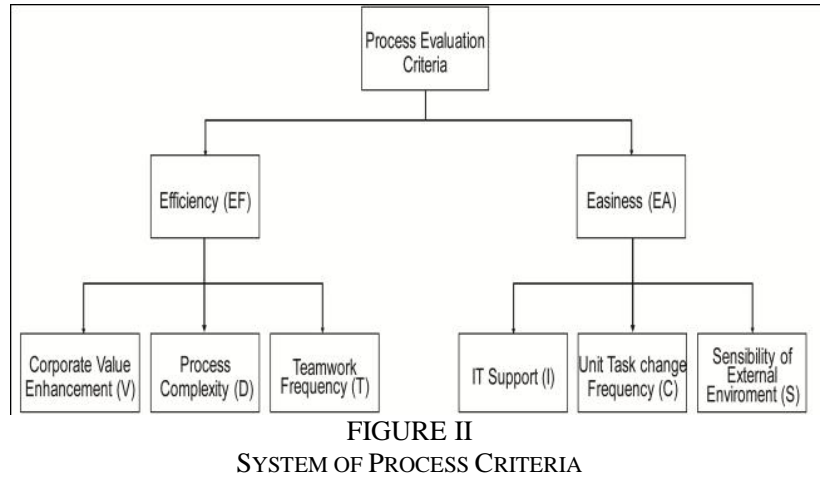

Process criteria are determined by Efficiency (EF) and Ease (EA), each having a relative importance to ratio of $1: 1$. It is computed by multiplying each criterion's importance by the results of the unit task. In the case of a strategic management business, for example, it is calculated by multiplying corporate value enhancement, process complexity, weight of frequency of cooperation, and quantitative results of each strategic management. Evaluation Ease also follows the procedure mentioned above that evaluates Efficiency and Ease of a strategic management business. Then we analyzed the priorities of BPM application. The priorities are distributed from group A to D. Thus, this paper suggests a sequential application plan for Business Process Management model.

In accordance with each criterion's weight and valuation results of the unit task, its result is classified into Efficiency and Easiness and computed by adding up each value. Efficiency is divided into 3 criteria which are, Enterprise Value, Process Complexity, and Frequency of Teamwork (T).1

$$
\begin{aligned}
& \text { Efficiency }(E F)=\left\{\left(\begin{array}{lll}
v & x v
\end{array}\right)+(d \times x d)+(t \times x t)\right\}
\end{aligned}
$$

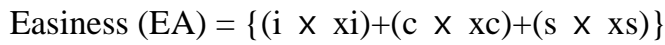

\section{3) Questionnaire outline}

These surveys were asked to staff from 11 companies who were in charge of management, HR, processing, finances \& economy, IT, or construction performance for at least 10 years. The return rate of the questionnaires was $75 \%$ out of 110 copies distributed and is as in Table 5.

(1) ${ }^{1}$ Corporate value enhancement $=$ Corporate value enhancement weight $(\mathrm{v}) \mathrm{x}$ its result $\left(\mathrm{x}_{\mathrm{v}}\right)$

(2) Process diversity $=$ Process diversity weight (d) $x$ its results $\left(x_{d}\right)$

(3) Teamwork frequency $(T)=$ Teamwork frequency weight $(t) x$ its results $\left(\mathrm{x}_{\mathrm{t}}\right)$

(4) IT Support (I) = IT Support weight (i) $\mathrm{x}$ its result $\left(\mathrm{x}_{\mathrm{i}}\right)$

(5) Frequency of unit task change $(\mathrm{C})=$ frequency of unit task change weight $(\mathrm{C})(\mathrm{c}) \mathrm{x}$ its result $\left(\mathrm{x}_{\mathrm{c}}\right)$

(6) Sensibility of external change $(S)=$ Sensibility of external change weight $(\mathrm{s}) \mathrm{x}$ its result $\left(\mathrm{x}_{\mathrm{s}}\right)$ 
TABLE V

QUESTIONNAIRES OUTLINE

\begin{tabular}{c|l}
\hline Criteria & \multicolumn{1}{|c}{ Contents } \\
\hline \multirow{3}{*}{ Purpose } & $\begin{array}{l}\text { (1) Analyzing the importance of each criteria and } \\
\text { choosing core area for BPM model application } \\
\text { (2) Evaluation of the priorities of BPM model application } \\
\text { on each unit task }\end{array}$ \\
\hline Target & $\begin{array}{l}\text { Staff who were in charge of management, HR, } \\
\text { processing, finances \& economy, IT, or construction } \\
\text { performance (11 domestic general contractors) }\end{array}$ \\
\hline \multirow{2}{*}{$\begin{array}{l}\text { Research } \\
\text { Methods }\end{array}$} & $\begin{array}{l}\text { Step 1: Introduce the survey and confirm participants } \\
\text { consent by telephone. } \\
\text { Step 2: Introduce the concept of the survey. Explain how } \\
\text { to fill out the questionnaire and perform personal visit. }\end{array}$ \\
Step 3: Collect the results by mail or visiting. \\
rate & $\begin{array}{l}\text { - Number of total copies distributed: 110 } \\
\text { - Contractors : 11 companies, each 10 copies } \\
\text { - Replied copies : 83 } \\
\text { - Return rate : 75\% }\end{array}$ \\
\hline
\end{tabular}

4) Priority analysis result by applying sequential BPM

Table 6 and 7 shows the result of the importance of each evaluation criteria through $\mathrm{CI}$ analysis result which were consistent among all 83 respondents. The arithmetic average in the table presents the importance of each evaluation criteria. Importance of the efficiency in the criteria is as in Table 6. According to the table, corporate value enhancement rate is $33.96 \%$, process complexity $34.35 \%$, and teamwork frequency $31.69 \%$.

TABLE VI

IMPORTANCE OF EFFICIENCY IN THE CRITERIA

\begin{tabular}{c|c|c|c|c|c|c|c|c|c|c|c|c}
\multicolumn{8}{c}{ IMPORTANCE OF EFFICIENCY IN THE CRITERIA } \\
\hline Criteria & $\begin{array}{c}\text { A } \\
(5)\end{array}$ & $\begin{array}{c}\text { C } \\
(4)\end{array}$ & $\begin{array}{c}\text { D } \\
(7)\end{array}$ & $\begin{array}{c}\text { E } \\
(5)\end{array}$ & $\begin{array}{c}\text { F } \\
(3)\end{array}$ & $\begin{array}{c}\text { G } \\
(2)\end{array}$ & $\begin{array}{c}\text { H } \\
(3)\end{array}$ & $\begin{array}{c}\text { I } \\
(4)\end{array}$ & $\begin{array}{c}\text { J } \\
(1)\end{array}$ & $\begin{array}{c}\text { K } \\
(7)\end{array}$ & $\begin{array}{c}\text { Sum } \\
(41)\end{array}$ & $\begin{array}{c}\text { Arithmetic } \\
\text { average }\end{array}$ \\
\hline $\begin{array}{c}\text { Corporate Value } \\
\text { Enhancement }\end{array}$ & 1.56 & 0.59 & 3.00 & 1.91 & 0.79 & 0.30 & 1.16 & 0.91 & 0.20 & 3.46 & 13.92 & 0.33 \\
\hline Process Complexity & 1.41 & 2.07 & 2.53 & 1.22 & 1.42 & 0.80 & 0.91 & 1.61 & 0.60 & 1.46 & 14.08 & 0.34 \\
\hline Teamwork Frequency & 2.02 & 1.32 & 1.46 & 1.86 & 0.78 & 0.88 & 0.91 & 1.46 & 0.20 & 2.06 & 12.99 & 0.31 \\
\hline
\end{tabular}

Meanwhile, the easiness of importance of criteria is as in table 5 .

TABLE VII

IMPORTANCE OF EASINESS IN THE CRITERIA

\begin{tabular}{c|c|c|c|c|c|c|c|c|c|c|c|c}
\hline Criteria & $\begin{array}{c}\mathrm{A} \\
(4)\end{array}$ & $\begin{array}{c}\mathrm{C} \\
(5)\end{array}$ & $\begin{array}{c}\mathrm{D} \\
(7)\end{array}$ & $\begin{array}{c}\mathrm{E} \\
(5)\end{array}$ & $\begin{array}{c}\mathrm{F} \\
(5)\end{array}$ & $\begin{array}{c}\mathrm{G} \\
(1)\end{array}$ & $\begin{array}{c}\mathrm{H} \\
(5)\end{array}$ & $\begin{array}{c}\mathrm{I} \\
(5)\end{array}$ & $\begin{array}{c}\mathrm{J} \\
(3)\end{array}$ & $\begin{array}{c}\mathrm{K} \\
(5)\end{array}$ & $\begin{array}{c}\text { Sum } \\
(45)\end{array}$ & $\begin{array}{c}\text { Arithmetic } \\
\text { average }\end{array}$ \\
\hline IT Support & 1.98 & 1.96 & 2.55 & 1.41 & 1.68 & 0.44 & 1.23 & 1.35 & 0.26 & 1.78 & 14.68 & 0.32 \\
\hline $\begin{array}{c}\text { Frequency of } \\
\text { process change }\end{array}$ & 0.79 & 1.85 & 3.01 & 1.42 & 1.82 & 0.11 & 2.12 & 1.00 & 1.33 & 1.92 & 15.42 & 0.34 \\
\hline $\begin{array}{c}\text { Sensibility of } \\
\text { external change }\end{array}$ & 1.22 & 1.17 & 1.43 & 2.16 & 1.48 & 0.44 & 1.63 & 2.63 & 1.40 & 1.28 & 14.89 & 0.33 \\
\hline
\end{tabular}

The result of application priority survey of process chain level based on Efficiency (corporate value enhancement, diversity of process, and teamwork frequency of business unit) and Easiness (IT support, frequency of unit task change, and sensibility of external change) is shown in Table 8.
TABLE VIII

BUSINESS SUPPORT

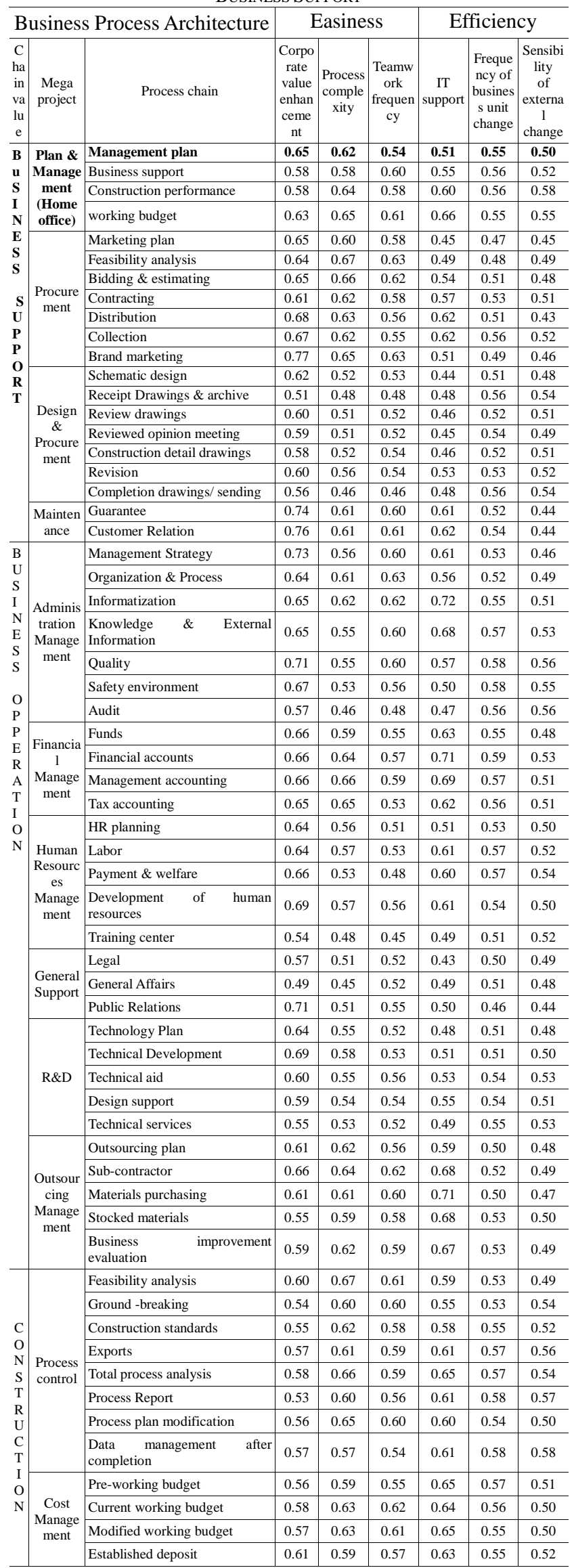




\begin{tabular}{|c|c|c|c|c|c|c|c|}
\hline & $\begin{array}{l}\text { Analysis of investment compare } \\
\text { to establishment }\end{array}$ & 0.61 & 0.59 & 0.57 & 0.63 & 0.54 & 0.53 \\
\hline & Break-even analysis & 0.65 & 0.65 & 0.58 & 0.65 & 0.54 & 0.51 \\
\hline & Accurate account of completion & 0.61 & 0.60 & 0.58 & 0.62 & 0.55 & 0.53 \\
\hline \multirow{3}{*}{$\begin{array}{c}\text { Estimate } \\
\text { manage } \\
\text { ment }\end{array}$} & Preview & 0.56 & 0.54 & 0.54 & 0.52 & 0.55 & 0.53 \\
\hline & Estimate & 0.58 & 0.58 & 0.58 & 0.58 & 0.53 & 0.53 \\
\hline & Reviewing the result \& Sending & 0.55 & 0.54 & 0.52 & 0.54 & 0.56 & 0.57 \\
\hline \multirow{7}{*}{$\begin{array}{c}\text { Material } \\
\text { manage } \\
\text { ment }\end{array}$} & Plan for material required & 0.51 & 0.54 & 0.53 & 0.58 & 0.52 & 0.46 \\
\hline & Customer payment & 0.53 & 0.53 & 0.52 & 0.59 & 0.52 & 0.53 \\
\hline & Sub-contractor procurement & 0.55 & 0.57 & 0.54 & 0.61 & 0.52 & 0.49 \\
\hline & Company procurement & 0.57 & 0.59 & 0.56 & 0.65 & 0.49 & 0.48 \\
\hline & Warehousing & 0.54 & 0.55 & 0.49 & 0.65 & 0.51 & 0.51 \\
\hline & Delivery & 0.52 & 0.55 & 0.52 & 0.64 & 0.51 & 0.51 \\
\hline & Material sum & 0.51 & 0.53 & 0.50 & 0.65 & 0.54 & 0.54 \\
\hline \multirow{3}{*}{$\begin{array}{c}\text { Labor } \\
\text { manage } \\
\text { ment }\end{array}$} & Mobilization plan & 0.50 & 0.47 & 0.44 & 0.49 & 0.55 & 0.54 \\
\hline & Registration & 0.45 & 0.42 & 0.44 & 0.60 & 0.53 & 0.60 \\
\hline & Status of labor use & 0.47 & 0.45 & 0.48 & 0.61 & 0.55 & 0.62 \\
\hline \multirow{6}{*}{$\begin{array}{c}\text { Sub- } \\
\text { contract } \\
\text { or } \\
\text { manage } \\
\text { ment }\end{array}$} & Selection & 0.61 & 0.58 & 0.57 & 0.62 & 0.49 & 0.47 \\
\hline & \begin{tabular}{|l|} 
Registration \\
\end{tabular} & 0.56 & 0.54 & 0.52 & 0.65 & 0.51 & 0.51 \\
\hline & Establishment & 0.57 & 0.61 & 0.56 & 0.66 & 0.53 & 0.52 \\
\hline & Change \& contract & 0.58 & 0.62 & 0.57 & 0.66 & 0.53 & 0.49 \\
\hline & Handling bankrupts & 0.60 & 0.62 & 0.57 & 0.56 & 0.55 & 0.44 \\
\hline & Evaluating & 0.63 & 0.59 & 0.56 & 0.67 & 0.55 & 0.52 \\
\hline \multirow{7}{*}{$\begin{array}{l}\text { Quality } \\
\text { control }\end{array}$} & Plan & 0.64 & 0.54 & 0.53 & 0.47 & 0.58 & 0.53 \\
\hline & Inspection in factory & 0.60 & 0.51 & 0.55 & 0.42 & 0.59 & 0.55 \\
\hline & Undertaking inspection & 0.60 & 0.52 & 0.54 & 0.44 & 0.60 & 0.53 \\
\hline & Inspection in process & 0.62 & 0.53 & 0.56 & 0.44 & 0.59 & 0.57 \\
\hline & Incongruity measure & 0.66 & 0.57 & 0.58 & 0.44 & 0.58 & 0.54 \\
\hline & Corrective measure & 0.66 & 0.57 & 0.56 & 0.46 & 0.60 & 0.57 \\
\hline & Quality analysis \& Evaluating & 0.68 & 0.59 & 0.58 & 0.52 & 0.55 & 0.54 \\
\hline \multirow{10}{*}{$\begin{array}{c}\text { Defectio } \\
\mathrm{n} \\
\text { Manage } \\
\text { ment }\end{array}$} & Interm check for Public space & 0.62 & 0.56 & 0.52 & 0.48 & 0.54 & 0.52 \\
\hline & Interior quality check & 0.66 & 0.56 & 0.54 & 0.51 & 0.54 & 0.50 \\
\hline & Previous check for tenant & 0.69 & 0.57 & 0.57 & 0.56 & 0.53 & 0.51 \\
\hline & Final quality check & 0.72 & 0.60 & 0.55 & 0.56 & 0.52 & 0.50 \\
\hline & Moving into management & 0.71 & 0.56 & 0.54 & 0.62 & 0.55 & 0.50 \\
\hline & Application \& Treatment & 0.73 & 0.59 & 0.57 & 0.60 & 0.57 & 0.50 \\
\hline & Budget & 0.59 & 0.54 & 0.50 & 0.56 & 0.56 & 0.52 \\
\hline & Execution & 0.66 & 0.58 & 0.55 & 0.56 & 0.55 & 0.53 \\
\hline & Verification & 0.65 & 0.58 & 0.56 & 0.54 & 0.55 & 0.54 \\
\hline & Analysis \& Evaluating & 0.66 & 0.63 & 0.54 & 0.64 & 0.53 & 0.51 \\
\hline
\end{tabular}

\section{5) Analyzed result of application priority for sequential BPM model}

Efficiency (EF) and Easiness (EA) was applied in a BPM model to each business unit. Efficiency scored 0.58 out of 1 while Easiness scored 0.53 . We divided the BPM model application priorities into 4 groups, according to their arithmetical average, which is as in fig. 3 .

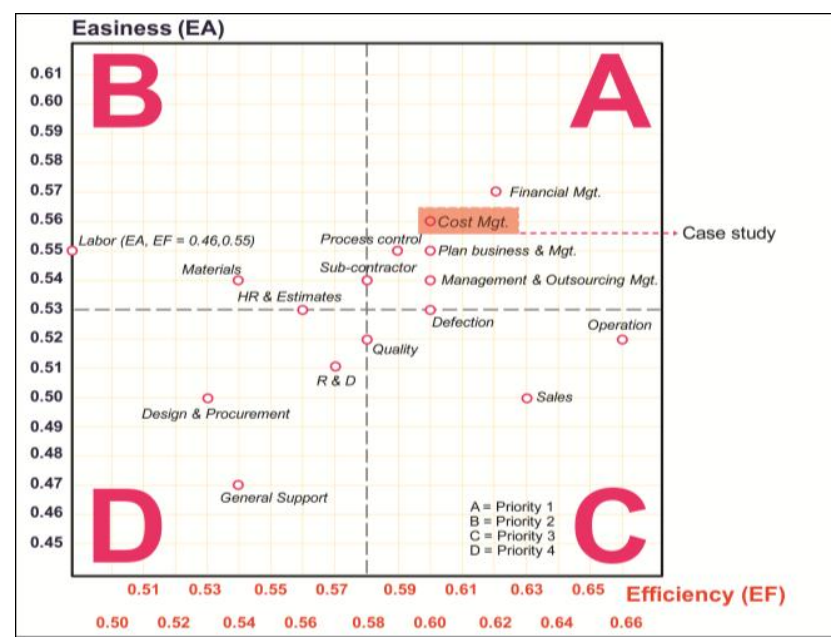

FIGURE III

APPLICATION PRIORITY FOR SEQUENTIAL BPM MODEL
The application of sequential BPM model was considered reasonable to start from group $\mathrm{A}$, which includes finance, cost, management plan, schedule, administration, and outsourcing.

\section{CASE STUdy FOR SEQUENTIAL APPLICATION OF BPM}

\section{A. Present condition and problems of cost management}

This paper proposes a sustainable business process management model, an algorithm, and a BPM system, focusing on cost management, which is regarded a top priority in the aspect of efficiency and easiness, the result based on priority analysis for gradual adoption of BPM model.

Cost management in the head office of construction firms is performed by various operating bodies such as estimation team, construction management team, finance team and site manager. Typical applications for cost management are MIS(Management Information System), unit cost management system, approximate estimate systems, amount calculation systems, completed amount management systems, etc. For example, the main task of an estimate team is cost management, unit price negotiation, approximate estimate, and general estimate. They also input the business data of actual results, standard unit prices, sum and analysis of actual unit prices, approximate estimate, and cost breakdown system to the applications.

However, in cost management business process, dependence on business operators in the management process is too excessive. Also, although current cost management business process manages partial business process based on current information system, it has turned out to be difficult to progress, and to continuously monitor and eliminate unnecessary work.

There are six main factors that cause poor efficiency in cost management: delay in payment requested by site; long payment period; difficulty in grasping present status of cost management business; delay of operation budgeting; and delay in grasping cash flow at each construction site. Fig.4. is a characteristic diagram drawing the major problems of current cost management.

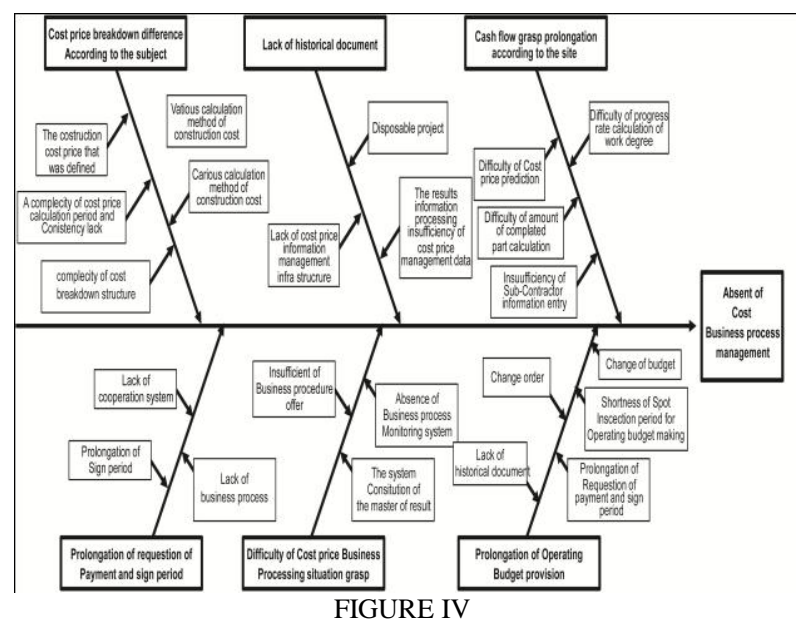

Fish BONE DiAGRAM FOR MAJOR PROBLEMS OF CURRENT COST MANAGEMENT 


\section{B. Structure of BPM model}

BPM model offers continuous improvement by eliminating inefficient elements in operating practical business system, and enables the execution of business process, monitoring, and measuring result. It also enables the management to keep on with BPM by the data provided for setting up future business strategy. The elements of BPM are composed of the following functions: process engine, information management, process monitoring, result measuring, and process improvement.

Fig.5. shows the architecture of the BPM model that reflects the design principle of the BPM model incorporating improvement for major problems of unit business in construction firms.

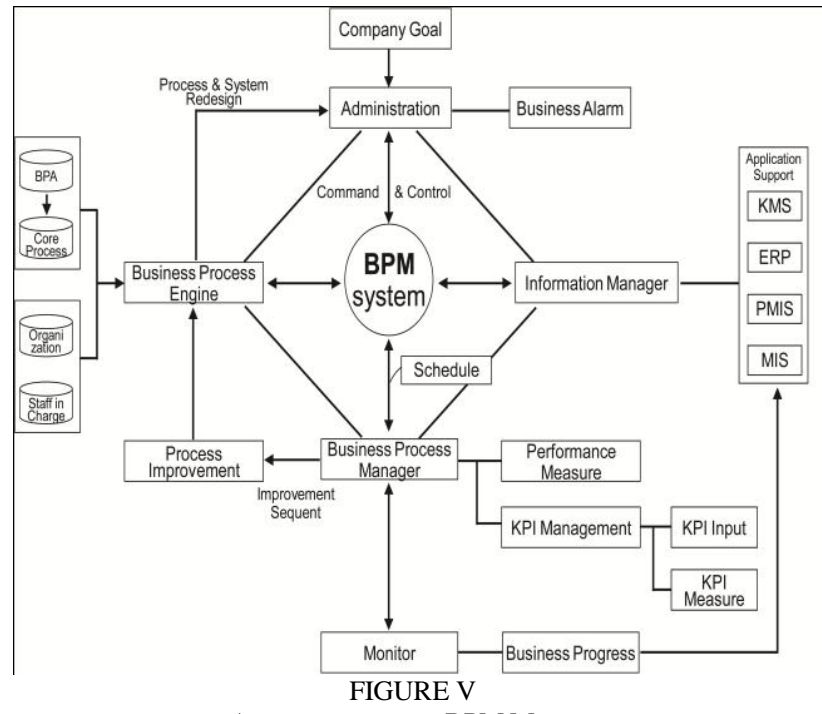

ARCHITECTURE OF BPM MODEL

The module of BPM model is largely categorized into 7 elements: ties with company strategy, manager, business process engine, information manager, business process manager, monitoring system, and continuous improvement.

The module of ties with company strategy is for reflecting the core strategy of construction firms and planning future strategies. The business process engine has a function to search the process undertaken by an officer in charge in accordance with the code of business process structure, and is a module to support managing process for officers in charge, and it is also interlinked with the information manager module so that one can carry out tasks based on the process. The business process manager module is to measure results and manage KPI (Key Performance Index) continuously, and is also interlinked with business monitoring module. The manager module is designed to continuously reflect improvements in relation with tasks, information support and business improvement, and is to control business. This module plays a role as an information provider for formulating future company strategy.

\section{Development of BPM model in cost management ${ }^{2}$}

Fig.6. shows the business flow modeling of unit activities related with each other in line with performing cost management. This analysis focuses on operation budget management and cost management of on-site office among other head office activities. The flow of operation budget management plays a fundamental role in realizing the prototype.

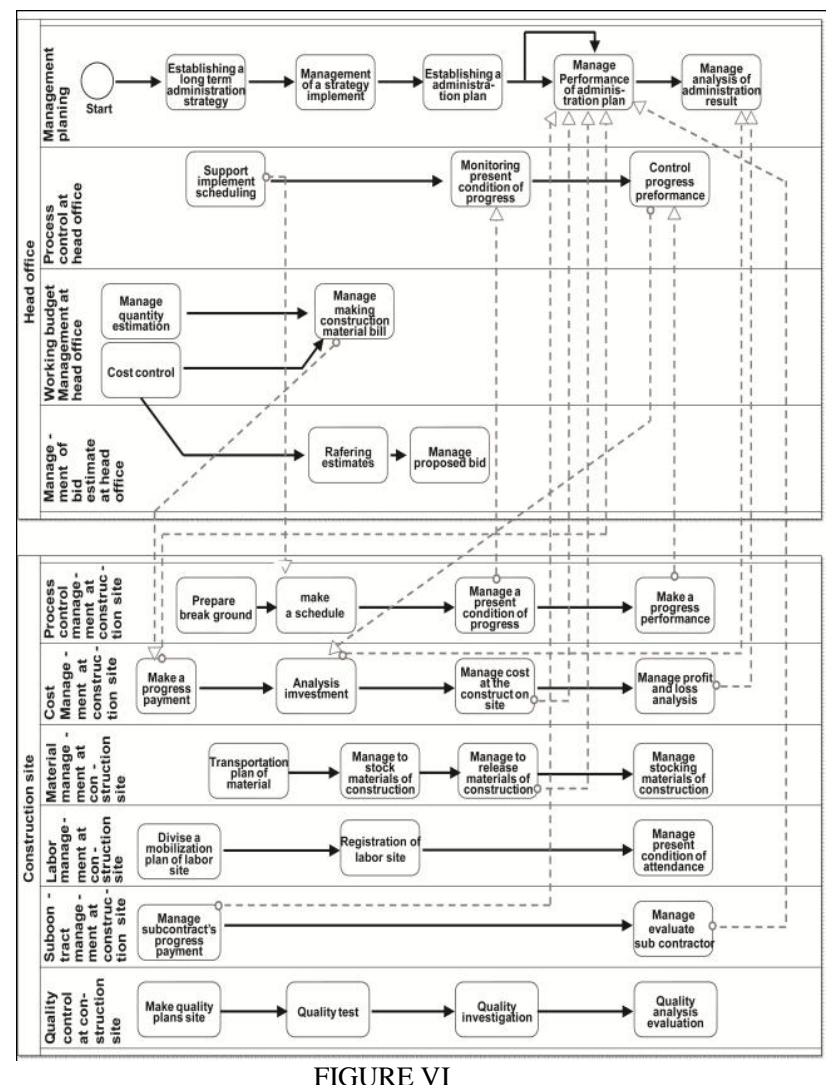

ANALysis OF THE COST MANAGEMENT PROCESS

Business process monitoring is divided into two monitoring systems, one for task manager and the other for task operator. The monitoring system for task operator monitors the preceding operator, the follow-up operator, and the current status of a task. The monitoring system for a task manager provides integrated functions, such as checking a process on company level and taking actions on a process that has been delayed or are in trouble. Task operators can check the preceding status of their task process and the follow-up operator of the task, and monitor the status and results of their task. Also, in this system, the current status of a task, completed, delayed,

\footnotetext{
${ }^{2}$ The operation environment for a prototype to adopt the BPM model in construction firms is as follow:

- Operation environment : Based on JAVA, WAS is JEUS by T-Max Software

- Solution : Biz Master by T-Max Software

- Display Screen of BPM process : Trust Form(X-Internet) by Comsquare Software

- Database : Oracle 10G
} 
etc. the process is visualized so that the operator can check operating bodies of each task.

In the senior manager's area, managers can check the integrated information of each process at enterprise level, and the status of each process, such as delayed, on-time, or early finished. When a manager clicks 'Detailed Information' icon, the manager can check the process status and the operator of each task. Fig.7. shows this process

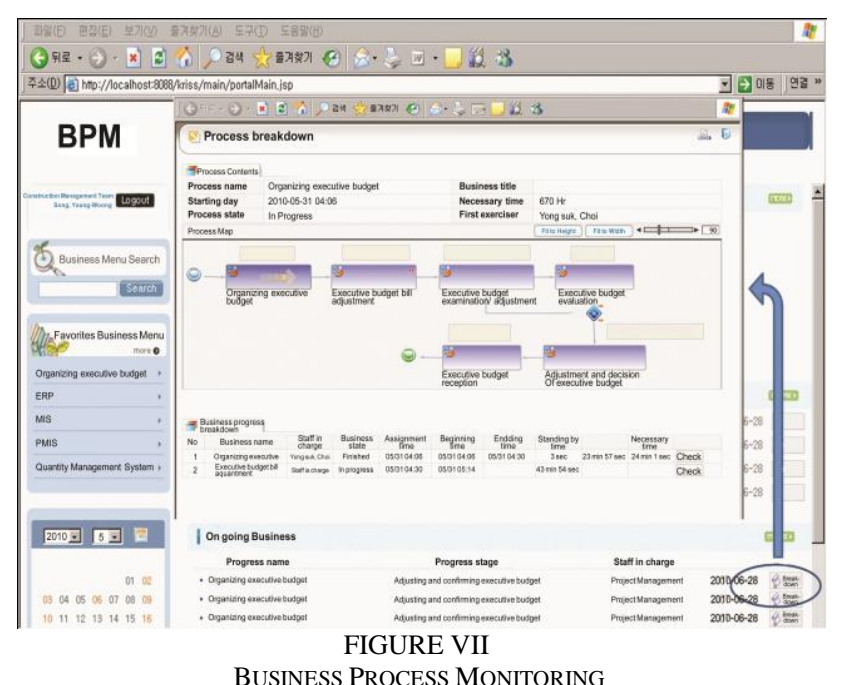

KPI for continuous management of BPM model is managed from respective process and organizational point of view. Furthermore, KPI management shows the performance status of a business process, which construction companies can utilize as fundamental data for establishing future business strategy.

The performance measurement demonstrates the performance of each process selected through Explorer, and it also shows grades based on the results of the evaluation item and actual performance vs. goal of each KPI. It also demonstrates the ups and downs of current performance compared to the performance of past. Fig. 8 shows this process.

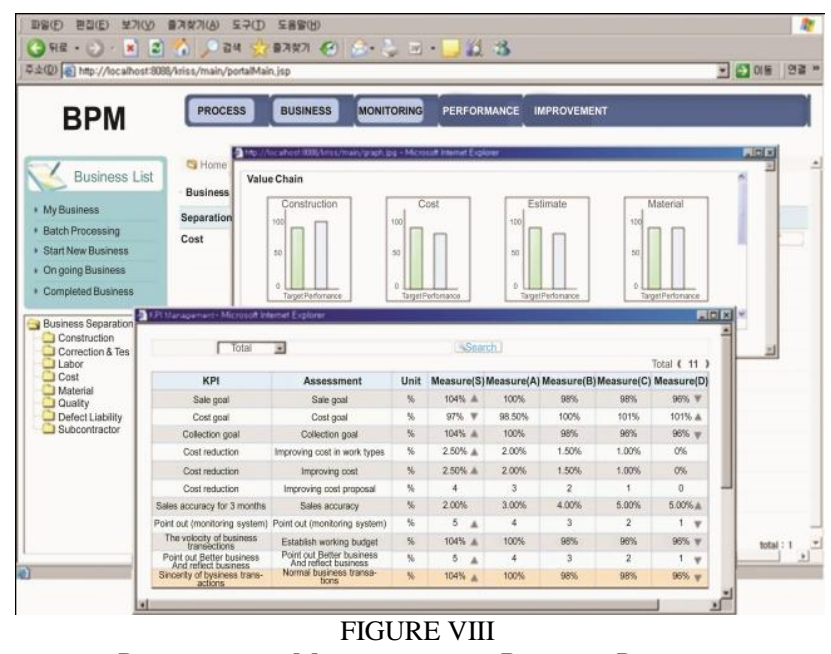

Performance Management of Business Process

\section{Expected Outcomes of the BPM Model}

TABLE IX

OUTLINES OF THE SURVEY FOR EXPECTED OUTCOME

\begin{tabular}{c|l}
\hline Category & \multicolumn{1}{c}{ Description } \\
\hline Target & $\begin{array}{l}\text { Working-level staff - with experience of more than 10 years } \\
\text { - from 11 construction companies' Management, Human } \\
\text { Resource Mgt., Process innovation, Financing and IT } \\
\text { division in Korea. }\end{array}$ \\
\hline Concept & $\begin{array}{l}\text { Expected outcome of the BPM model } \\
\text { Qualitative effects and list of BPM } \\
\text { Improved function as a result to applying BPM model }\end{array}$ \\
\hline $\begin{array}{c}\text { Analytical } \\
\text { Method }\end{array}$ & $\begin{array}{l}\text { lelect 5 among 12 items to rank as five points, four points, } \\
\text { three points, two points and one point of the value-added } \\
\text { scores }\end{array}$ \\
\hline $\begin{array}{c}\text { Return } \\
\text { Rate }\end{array}$ & $\begin{array}{l}\text { Number of total copies : 110 } \\
\text { Replied copies : 83 } \\
\text { Return Rate : 75\% }\end{array}$ \\
\hline
\end{tabular}

The analysis of the effects of BPM reveals that the most anticipated outcome (21\%) is 'to reinforce implementation capacity of a process in harmony with the organization and IT system' as shown in Figure 6. This is followed by 'securing process capability to promptly respond to internal and external demands for changes and business environment changes (16\%)', 'effective collaboration and communication (15\%)', 'real-time evaluation of progress status and outcomes (13\%)', 'expedited work execution (12\%)', 'reduced work load and complexity $(9 \%)$ ', and 'increased productivity and profit $(8 \%)$.

\section{CONCLUSION}

This study reveals ways to improve the internal and external business processes of construction companies by adopting BPM interlinked with company strategy and proposed operating bodies and system. Furthermore, this study suggests a business process model which aims to realize continuous improvement through control and monitoring of business procedures. To reduce problems in cost management, which was selected as the top priority business area in applying BPM, we suggested a characteristic diagram of cost management, visualizing business process that could enable businesses to rearrange human resources and systems related to business operation based on business process.

We analyzed opportunities of improving current business process in cost management and thus proposed business process management model and algorithm. Furthermore, we designed BPM model which consists of 7 elements: interlinked company strategy, managers, business process engine, information management, business process management, monitoring, and continuous improvement, finally suggesting a BPM system architecture model.

We suggested the model by analyzing each business unit to propose and generalize value chain and business process architecture suitable for construction industry. Furthermore, by evaluating each business unit (which is included in the business process architecture), based on quantitative standards, we presented a sequential 
application plan for business process model.

We finally developed a BPM model with functions of business process performance, monitoring, measuring performance, and eliminating inefficient elements. Through this system, construction companies can achieve efficiency and agility thanks to business process improvement and building-up information-oriented strategy at the same time. In conclusion, adopting the model could assist construction companies realize a fundamental business process management system which could continuously improve, enabling construction companies to adapt to the constant changes of market environment.

\section{ACKNOWLEDGEMENT}

This work was supported by the National Research Foundation of Korea Grant funded by the Korean Government(Ministry of Education, Science and Technology).[NRF-2010-359-D00027]

\section{REFERENCES}

[1] H. Smith, P. Fingar, "BPM, The Third Wave analysis", Sigma Insight, 2002.

[2] D. Elzinga, "Business Process Management - Survey and Methodology", 1995.

[3] L. Verner, "BPM - The Promise and the Challenge", 2004.

[4] B.O. Lee, "A study on the Case of Implementing BPM of a Manufacturing Company analysis", Master's thesis, Graduate School of Inje University, 2004.

[5] J.H. Choi, J. Lee, "A Study of Process Selection and Implementation for Business Process Management analysis", Information System Review, vol. 8, no. 1, pp. 25-41, 2006.

[6] Daelim Industry, "Report on BPM Implementation", Company's Report, 2004.

[7] Bearing Point, "BPM Implementation Strategy Report", Company's Report, 2004.

[8] Handy Soft, "Report on BPM Implementation", Company's Report, 2006.

[9] W.E. Deming, "Out of the crisis", MIT, Center for Advanced Engineering Study, 1986.

[10] Y.W. Song, "A Study of a Sustainable Business Process Management Model for a Construction Company", Ph. D's Thesis, SoongSil University, 2007.

[11] S.K. Lee, "Critical Success Factors for Project Management Information System in Construction", Journal of Construction Engineering and Project Management, vol. 1, no. 1, pp. 25-30, 2011.

[12] S.K. Lee, "Assessment of ASP-PMIS Quality in Korea", Journal of Construction Engineering and Project Management, vol. 1, no. 3, pp. 9-17, 2011.

[13] J.H. Yu, "Evaluation Model for Information Systems Benefits in Construction Management Process", Journal of Construction Engineering and Management, vol. 132, no. 10, pp. 1114-1121, 2006.

[14] J.H. Park, "Deriving an ASP Success Model : An Application to Small Business", Business Information Research, vol. 14, no. 1, pp. 43-58, 2004.

[15] H.Y. Lin, "ERP System Success: An Integration of IS Success Model and Balanced Scorecard", Journal of Research and Practice in Information Technology, vol. 38, no. 3, pp. 215-228, 2006. 